\title{
Assessment of Knowledge and Attitude Regarding Female and Male Breast Cancer among Adults of South India
}

Anwitha Johns, Satish Kumar B P \& Lavanya P R

Adichunchanagiri University

\section{ABSTRACT}

Background \& Objectives: Breast cancer is the second leading reason for cancer death in women. Incidence rates of male breast cancer have increased by $0.2-1 \%$ per year. The lack of knowledge and awareness of male breast cancer leads to its detection at a late stage in men. This study is to assess the knowledge and attitude of south Indian adults towards male and female breast cancer.

Methods: To assess the knowledge and attitude of adults on breast cancer, a questionnaire regarding basic knowledge and attitudes was formulated using Google forms. Numbers and percentages were formed to review categorical and nominal data. Chi-square $\left(\chi^{2}\right)$ test was used for the comparison between the awareness of female breast cancer and male breast cancer. $\mathrm{P}<0.05$ was set as the level of significance.

Keywords: NA

Classification: NLMC CODE: WP 840, QZ 20.5

Language: English 



\title{
Assessment of Knowledge and Attitude Regarding Female and Male Breast Cancer among Adults of South India
}

\author{
Anwitha Johns ${ }^{\alpha}$, Satish Kumar B $\mathrm{P}^{\sigma}$ \& Lavanya $\mathrm{P} \mathrm{R}^{\rho}$
}

\section{ABSTRACT}

Background \& Objectives: Breast cancer is the second leading reason for cancer death in women. Incidence rates of male breast cancer have increased by $0.2-1 \%$ per year. The lack of knowledge and awareness of male breast cancer leads to its detection at a late stage in men. This study is to assess the knowledge and attitude of south Indian adults towards male and female breast cancer.

Methods: To assess the knowledge and attitude of adults on breast cancer, a questionnaire regarding basic knowledge and attitudes was formulated using Google forms. Numbers and percentages were formed to review categorical and nominal data. Chi-square ( $\left.\chi^{2}\right)$ test was used for the comparison between the awareness of female breast cancer and male breast cancer. $P<$ o.05 was set as the level of significance.

Results: A total of 352 respondents enrolled in the study. 248 (70.5\%) were females and 104 (29.5\%) were males. A good number of participants 340 (96.6\%) were aware of female breast cancer and only 118 (33.5\%) of the participants heard about male breast cancer. An unsatisfactory number of participants perform breast self-examination once a month and start mammogram screening at the age of 40 .

Interpretation and Conclusions: Female breast cancer awareness was increased but lack of knowledge of screening techniques like breast self-examination and mammography doesn't decrease the prevalence of female breast cancer. Male breast cancer awareness was very poor and unsatisfactory. Educational training on screening techniques and community awareness programs should be conducted to decrease breast cancer prevalence.

Author: Sri Adichunchanagiri College of Pharmacy, Adichunchanagiri University, Karnataka, India.

\section{INTRODUCTION}

Uncontrolled growth of epithelial cells in the breast is termed Breast cancer or breast carcinoma. There are different categories of breast cancer. The category of breast cancer is determined by which cells in the breast turn into cancer.

Breast cancer can initiate in different parts of the breast. Three main parts of the breast are lobules, ducts, and connective tissue. The lobules are the glands responsible for the production of milk. The tubes responsible for carrying milk to the nipple are ducts. The connective tissue environs and embraces everything together. Breast cancers mostly initiate in the ducts or lobules. When breast cancer spreads to other parts of the body through blood vessels and lymph vessels, it is referred to as metastasized(1).

There is a drastic increase in the incidence of Breast Cancer in previously low incidence areas such as Asia. Particularly in India, breast cancer is considered leading cancer among women in certain cities such as Mumbai, Bangalore \& Thiruvananthapuram. According to the Indian Council of Medical Research-population Based Cancer Registry (ICMR-PBCR) information, breast cancer has turned into common cancer among females in urban registries of Delhi, Mumbai, Ahmedabad, Calcutta, and Trivandrum(2). 
In recent years, incidence rates of breast cancer have increased by $0.3 \%$ per year. After lung cancer, breast cancer is the second leading reason of cancer death in women. Probably 1 in 38 women die from breast cancer i.e about $2.6 \%$. Recent studies confirm that breast cancer prevalence is increasing year by year(3)

Comparative to female breast cancer, male breast carcinoma is uncommon, with an incidence of 1 in 100,000 men, which is accounting for less than $1 \%$ of all cases of breast carcinoma. Incidence rates of male breast cancer have increased by 0.2$1 \%$ per year(4).

Because of low incidence and very low awareness of male breast cancer, no clinical studies are giving appropriate information on the optimal diagnostics and proper treatment and management for male breast cancer patients. Therefore, the currently used treatment recommendations are based on the guidelines of breast cancer in women. However, the lack of knowledge and awareness of male breast cancer leads to its detection at a late and advanced stage in men accompanying an untreatable prognostic outcome (5).

This study is considered based on the increasing incidence of women breast cancer and very poor awareness of male breast cancer among adults in India.

\section{METHODS \\ 2.1 Development and content of the Questionnaire}

To assess the knowledge and attitude of adults (above the age of 18 years) on female and male breast cancer, an anonymous questionnaire with 15 questions regarding basic knowledge and attitudes was formulated using Google forms. The questionnaire was formulated in collaboration with an expert in the field. Simple random sampling was cast-off for picking the participants. Through email and WhatsApp, the link to the survey was circulated to the intended participants. The questionnaire was mainly focusing on the participant's responses to both male and female breast cancer. Lastly, it was inquired if the participant had any query on breast cancer. The questionnaire was kept live for eight weeks, and the individuals were reminded to fill it up.

Study Design: Observational cohort prospective study.

Study duration: October 2020 to December 2020.

\section{Sample size}

The minimum of 352 sample size was calculated using Raosoft software at a 95\% confidence interval with a $5 \%$ margin of error and with a response rate of $70 \%$.

\section{Inclusion Criteria}

South Indian adults (above the age of 18)

\section{Exclusion criteria}

People who were not interested to enrol in the study

\section{Statistical analysis}

Data was entered into Microsoft Excel spreadsheets and cross-checked for its accuracy. Obtained data were analysed using the IBM SPSS statistics software for windows, version 22 (Armonk, NY, USA). Numbers and percentages were formed to review categorical and nominal data. Variables used in the analysis included age, sex, education level and marital status. Besides, the Chi-square $\left(\chi^{2}\right)$ test was used for the comparison between the awareness of female breast cancer and male breast cancer. $\mathrm{P}<0.05$ was set as the level of significance.

\section{RESULTS}

\subsection{Socio-demographic characteristics}

A total of 352 respondents enrolled in the study. Of this, 248 (70.5\%) were females and 104 (29.5\%) were males. The mean age of the respondents was 24.05 \pm 8.1 years, where more than half of the participants (80.4\%) belongs to the age category 18-25 years and more than half of the participants (82.7\%) were unmarried. Undergraduate (61.6\%) and graduated (31.5\%) participants were more in number. All the socio-demographic characteristics are detailed in (Table 1). 
Table 1: Sociodemographic characteristics of the participants $(\mathrm{N}=352)$

\begin{tabular}{|c|c|c|}
\hline Variable & Participants (N) & Percentage (\%) \\
\hline \multicolumn{3}{|l|}{ Age in years } \\
\hline $18-25$ & 283 & 80.4 \\
\hline $26-35$ & 30 & 8.5 \\
\hline $36-45$ & 24 & 6.8 \\
\hline $46-55$ & 14 & 4.0 \\
\hline $56-65$ & oO & 0.0 \\
\hline 66 and above & 01 & 0.3 \\
\hline \multicolumn{3}{|l|}{ Sex } \\
\hline Female & 248 & 70.5 \\
\hline Male & 104 & 29.5 \\
\hline \multicolumn{3}{|l|}{ Marital status } \\
\hline Married & 61 & $17 \cdot 3$ \\
\hline Unmarried & 291 & 82.7 \\
\hline \multicolumn{3}{|l|}{ Education } \\
\hline Illiterate & 01 & 0.3 \\
\hline Primary education & 04 & 1.1 \\
\hline Secondary education & 19 & 5.4 \\
\hline Degree & 217 & 61.6 \\
\hline Any higher education & 111 & 31.5 \\
\hline
\end{tabular}

\subsection{Knowledge of the participants for breast cancer}

Among 352 participants, a good number of participants 340 (96.6\%) were aware of female breast cancer and only $118(33.5 \%)$ of the participants heard about male breast cancer (fig 1). About $58.8 \%$ population knew about the most breast cancer affected age group. Family history was marked several times (57.4\%) as the main reason for breast cancer, few (37.2\%) marked for early menses/late menopause but very few (19\%) thought that body weight would contribute to the breast cancer cause. 268 (76.1\%) were unaware that men diagnosed with breast cancer are more likely to die when compared to women (fig 2). According to the survey, the majority of the partici- pants (74.7\%) thinks breast cancer is a treatable disease. The complete information about knowle- dge for breast cancer is detailed in (Table 2). 
Table 2: Knowledge of the participants for breast cancer $(\mathrm{N}=352)$

\begin{tabular}{|c|c|c|}
\hline Questions & Yes & No \\
\hline \multicolumn{3}{|l|}{$\begin{array}{l}\text { 1. Have you heard about female breast } \\
\text { cancer and male breast cancer? }\end{array}$} \\
\hline a) Female breast cancer & $\begin{array}{l}340 \\
(96.6 \%)\end{array}$ & $\begin{array}{c}12 \\
(3.4 \%)\end{array}$ \\
\hline b) Male breast cancer & $\begin{array}{l}118 \\
(33.5 \%)\end{array}$ & $\begin{array}{l}234 \\
(66.5 \%)\end{array}$ \\
\hline $\begin{array}{l}\text { 2. Did you know } 50 \text { and above age groups } \\
\text { are most affected by breast cancer? }\end{array}$ & $\begin{array}{c}205 \\
(58.8 \%)\end{array}$ & $\begin{array}{c}145 \\
(41.2 \%)\end{array}$ \\
\hline \multicolumn{3}{|l|}{$\begin{array}{l}\text { 3. What do you think about the main } \\
\text { causes of breast cancer? }\end{array}$} \\
\hline a) Family history & $\begin{array}{c}202 \\
(57.4 \%)\end{array}$ & $\begin{array}{c}150 \\
(42.6 \%)\end{array}$ \\
\hline b) Early menses/Late menopause & $\begin{array}{l}131 \\
(37.2 \%)\end{array}$ & $\begin{array}{c}221 \\
(62.8 \%)\end{array}$ \\
\hline c) Bodyweight & $\begin{array}{l}67 \\
(19 \%)\end{array}$ & $\begin{array}{c}285 \\
(81 \%)\end{array}$ \\
\hline d) Food/ Personal hygiene & $\begin{array}{l}163 \\
(46.3 \%)\end{array}$ & $\begin{array}{c}189 \\
(53.7 \%)\end{array}$ \\
\hline $\begin{array}{l}\text { 4. Have you heard about } \\
\text { Breast Self-Examination(BSE)? }\end{array}$ & $\begin{array}{c}218 \\
(61.8 \%)\end{array}$ & $\begin{array}{c}134 \\
(38.1 \%)\end{array}$ \\
\hline $\begin{array}{l}\text { 5. Did you know the size differences of breasts in } \\
\text { youths are not the main reason for breast cancer? }\end{array}$ & $\begin{array}{c}205 \\
(58.2 \%)\end{array}$ & $\begin{array}{l}147 \\
(41.8 \%)\end{array}$ \\
\hline $\begin{array}{l}\text { 6. Did you know that Family history } \\
\text { (inherited genetics) is the main reason } \\
\text { for male breast cancer? }\end{array}$ & $\begin{array}{c}142 \\
(40.3 \%)\end{array}$ & $\begin{array}{c}210 \\
(59.7 \%)\end{array}$ \\
\hline $\begin{array}{l}\text { 7. Did you know that men diagnosed with } \\
\text { breast cancer are more likely to die when } \\
\text { compared to women? }\end{array}$ & $\begin{array}{c}84 \\
(23.9 \%)\end{array}$ & $\begin{array}{c}268 \\
(76.1 \%)\end{array}$ \\
\hline $\begin{array}{l}\text { 8. Do you think; breast cancer can be } \\
\text { treated? }\end{array}$ & $\begin{array}{c}263 \\
(74.7 \%)\end{array}$ & $\begin{array}{c}89 \\
(25 \cdot 3 \%)\end{array}$ \\
\hline
\end{tabular}

\subsection{The attitude of the participants for breast cancer}

Nearly $75 \%$ of the participants are willing to consult a doctor if they find any breast cancer symptoms. An unsatisfactory number of participants 30 (8.5\%) perform breast self-examination once a month (fig 3). More than half of the partic- ipants $(57.7 \%)$ are unaware of starting mammogram screening at the age of 40 (fig 4). The majority of the population (91.8\%) doesn't consider breast cancer as a contagious disease and they do not avoid contact with breast cancer patients. The complete information about attitude for breast cancer is detailed in (Table 3).

Table 3: Attitude of the participants towards breast cancer $(\mathrm{N}=352)$

\begin{tabular}{|ccc|}
\hline Questions & Yes & No \\
\hline 1. Would you consult a doctor if you found & 261 & 91 \\
with any of the breast cancer symptoms & $(74.1 \%)$ & $(25.9 \%)$ \\
\hline
\end{tabular}




\begin{tabular}{|lcc|}
\hline $\begin{array}{l}\text { 2. Do you perform breast self-examination } \\
\text { (BSE)? }\end{array}$ & $\begin{array}{c}131 \\
(37.2 \%)\end{array}$ & $\begin{array}{c}221 \\
(62.8 \%)\end{array}$ \\
\hline 3. Do you perform BSE once a month? & 30 & 322 \\
& $(8.5 \%)$ & $(91.5 \%)$ \\
\hline 4. Do you avoid contact with breast & 29 & 323 \\
cancer patients? & $(8.2 \%)$ & $(91.8 \%)$ \\
\hline 5. Are you aware of starting mammogram & 149 & 203 \\
screening at 40 years? & $(42.3 \%)$ & $(57.7 \%)$ \\
\hline
\end{tabular}

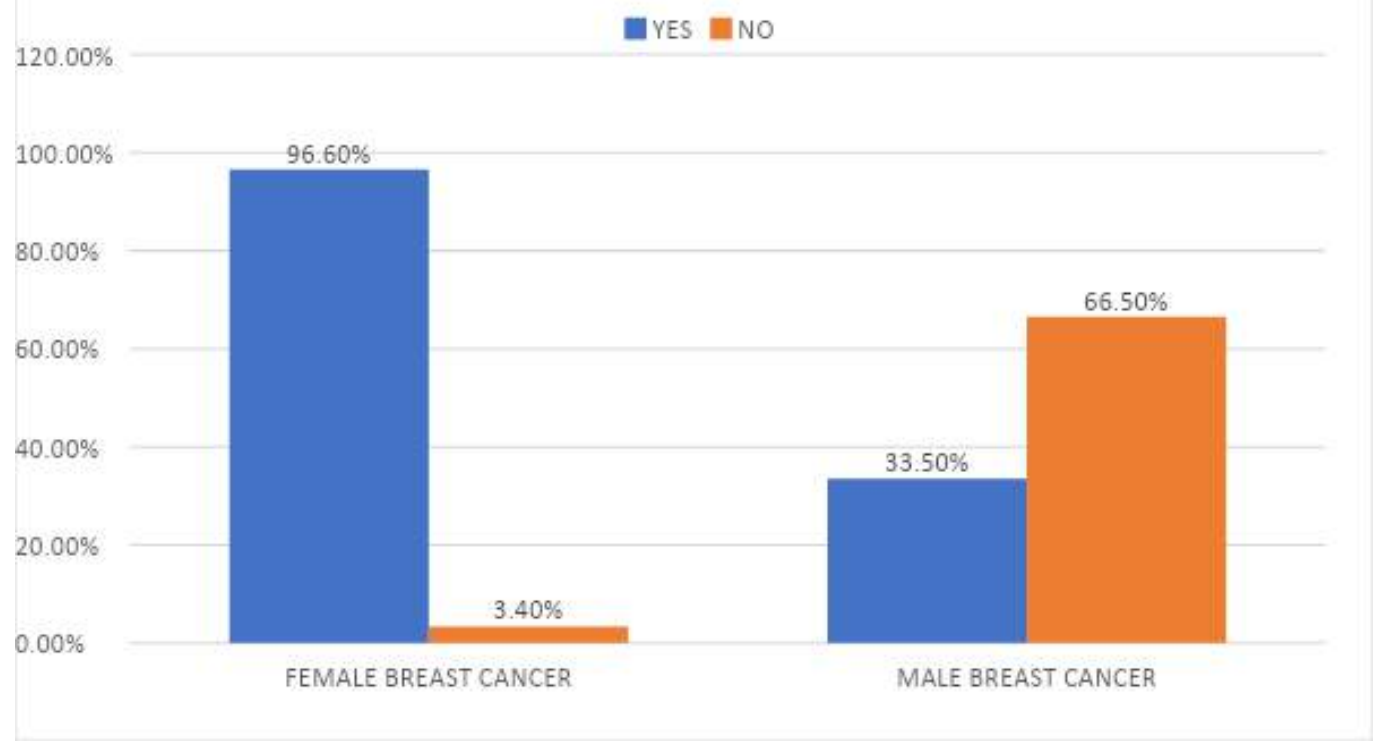

Figure 1: Have you heard about female breast cancer and male breast cancer

Figure 1 shows that a good number of participants the null hypothesis stating 'an equal percentage (96.6\%) were aware of female breast cancer and share of female breast cancer and male breast only a few (33.5\%) participants heard about male cancer awareness' is rejected. breast cancer. When the chi-square test is applied,

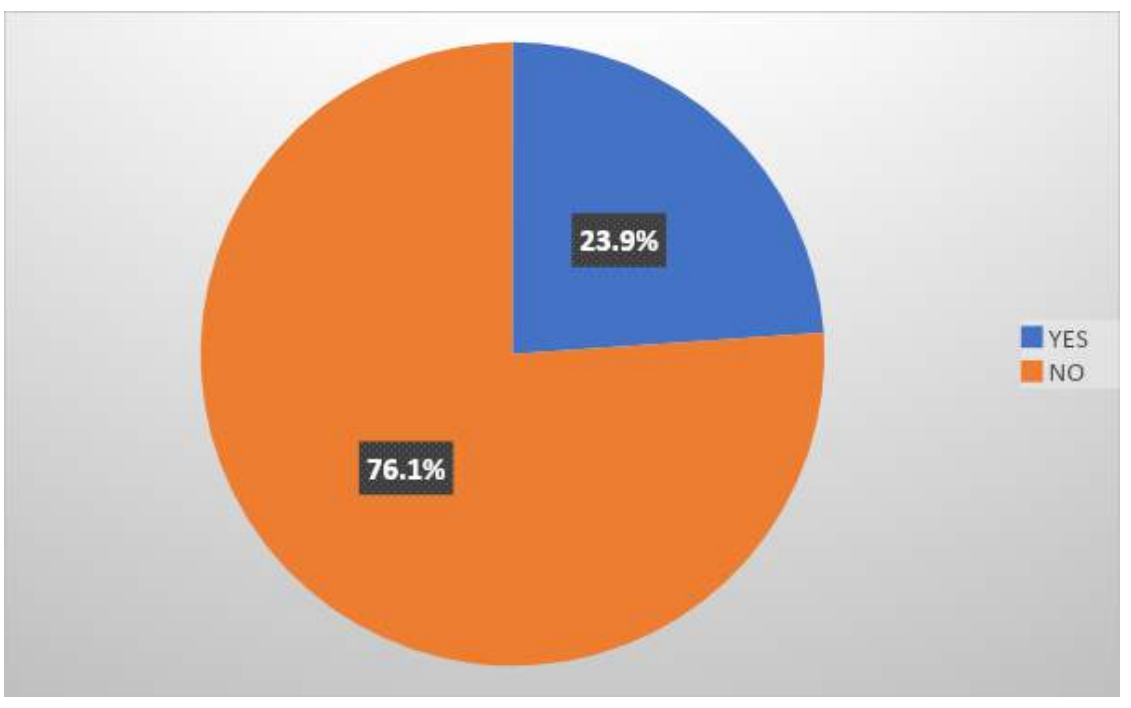

Figure 2: Did you know that men diagnosed with breast cancer are more likely to die when compared to women 
Figure 2 shows that $76.1 \%$ of participants were unaware that men diagnosed with breast cancer are more likely to die when compared to women.

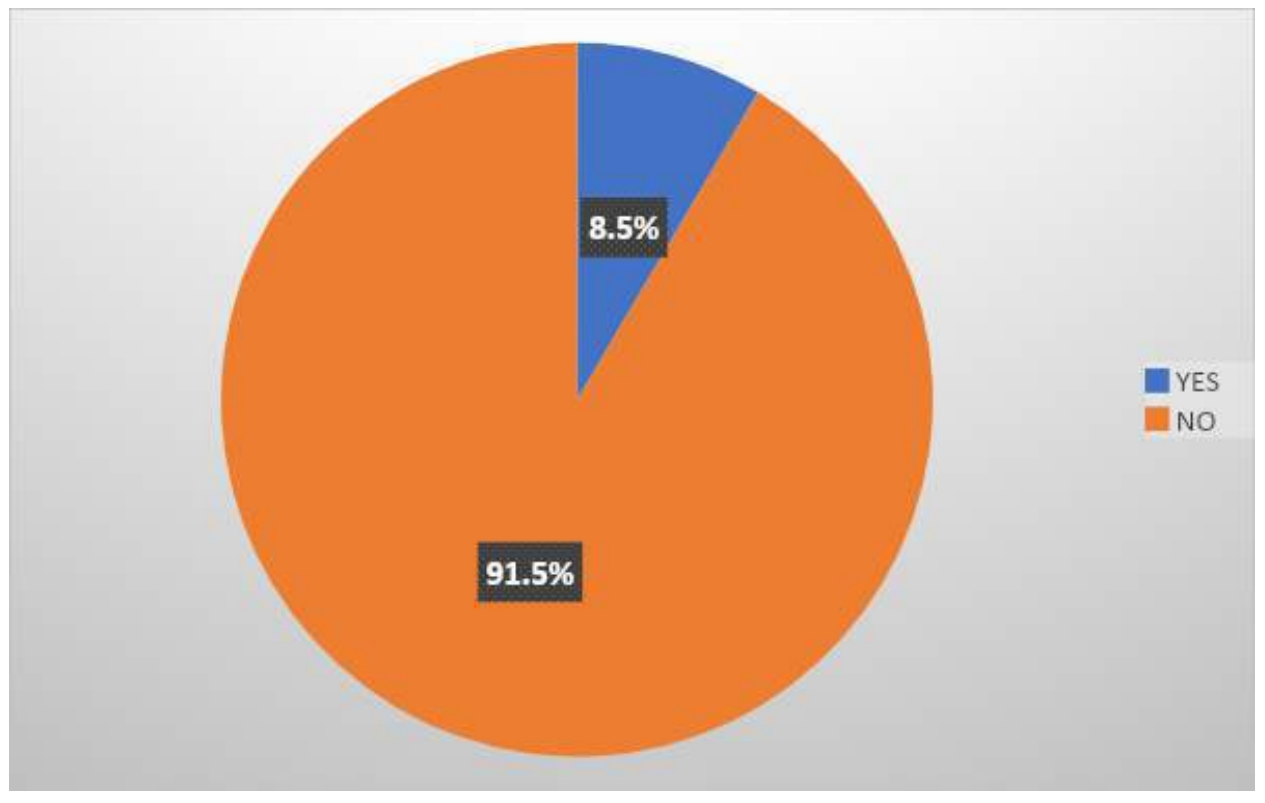

Figure 3: Do you Perform BSE once a month

Figure 3 explains, an unsatisfactory number of participants 30 (8.5\%) perform breast self-examination once a month.

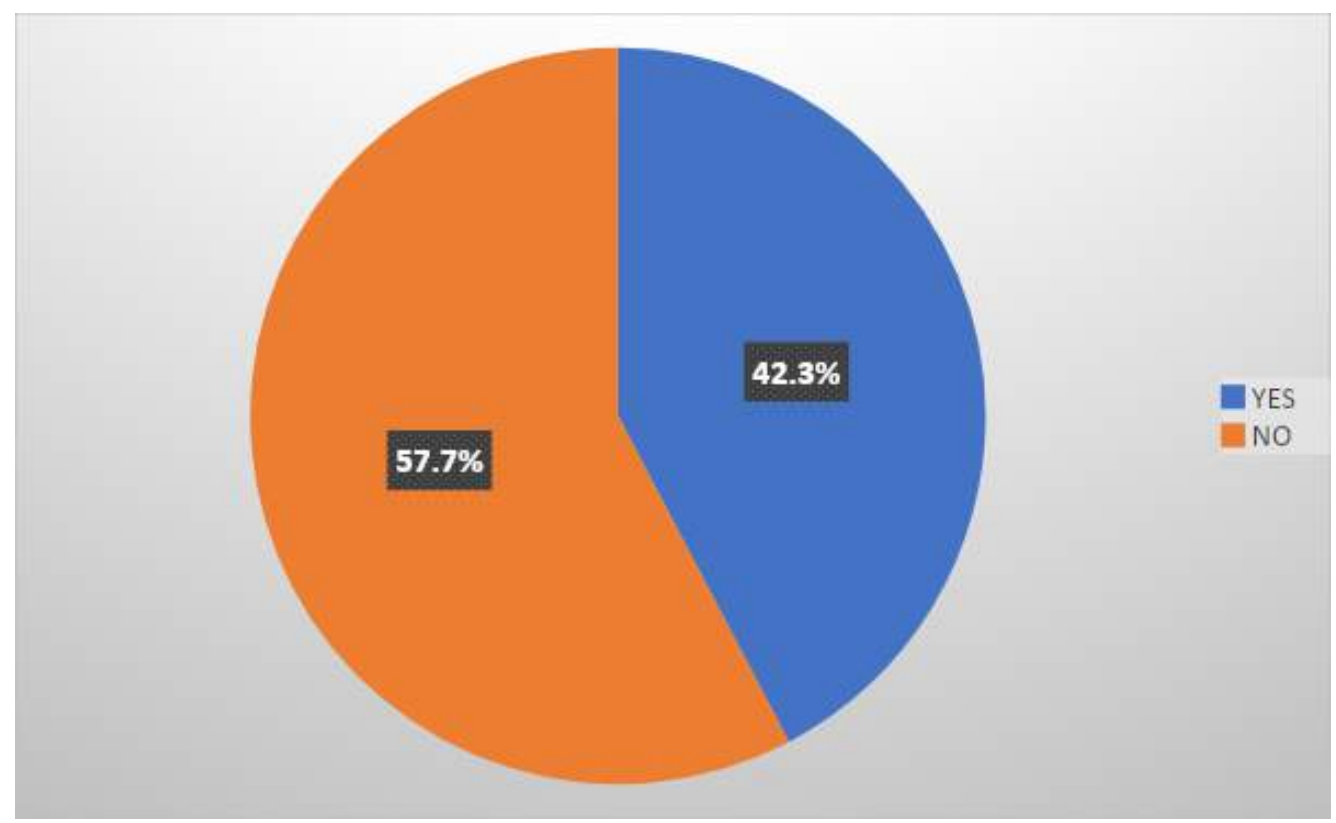

Figure 4: Are you aware of starting mammogram screening at 40 years

Figure 4 shows that more than half of the participants (57.7\%) are unaware of starting mammogram screening at the age of 40 . 


\section{DISCUSSION}

The purpose of the study is to assess the knowledge and attitude of South Indian adults towards female and male breast cancer and to estimate the awareness of female and male breast cancer. The need for the study is, breast cancer prevalence is increasing year by year and lack of awareness may be the reason for the increased prevalence. This study is believed to be the first of its kind in south India to assess awareness of male breast cancer in adults.

\subsection{Knowledge of the participants for breast cancer}

This study proves minimal knowledge and awareness of male breast cancer and maximum awareness of female breast cancer in south Indian adults. The last question in the questionnaire was to discuss if participants had any query on breast cancer and it proved that the majority of the participants were shocked to hear about male breast cancer. Most of the participants of the study were unaware that family history (inherited genetics) is the main reason for male breast cancer. The study conducted by Eileen Thomas showed nearly $80 \%$ of participants weren't aware that men can get breast cancer, and although all were at higher risk given their positive family history (6). Another study conducted by Jonathan White, Olive Kearins et.al, confirms the society opinion that the general public considers breast cancer as a female disease, and a diagnosis of male breast cancer is a sense of disbelief (7). The study conducted by Larissa A Korde, Jo Anne Zujewski et.al, states that education of both patients and healthcare professionals are required to increase awareness of male breast cancer, to direct evidence-based treatment, and to encourage clinical and biological studies intended at optimizing treatment for this rare disease (8).

\subsection{The attitude of the participants for breast cancer}

According to this study, the attitude of the participants towards breast cancer symptoms is satisfactory that the majority of the population consult a doctor if they found any breast cancer symptoms. The attitude towards the false belief, breast cancer is a contagious disease is very good that most of the participants do not avoid contact with breast cancer patients. But the attitude towards precautions and screening methods of breast cancer is very poor. According to the study by Ozgul Karayurt, Dilek Ozmen et.al, the females had inadequate knowledge about breast selfexamination and a low percentage of participants reported that they had done breast self-examination monthly (9). The study by Ahmed BA concluded that only $17.4 \%$ of participants were performing breast self-examination (BSE). The most known method of breast cancer detection was BSE, still, the majority never practice it because of a lack of knowledge about the technique (10). According to the study by SumadiL Anwar et.al, Only $5 \%$ of participants were aware of mammogram screening as the breast cancer screening technique(11). The study by Yusra E Elobaid et.al showed, almost half (44.8\%) of women never had a Clinical Breast Exam (CBE) and $44.1 \%$ of women who never had mammogram screening expressed ignorance about these screening techniques (12).

\section{CONCLUSION}

Female breast cancer awareness was increased and satisfactory but lack of knowledge of screening techniques like breast self-examination (BSE) and mammography doesn't decrease the prevalence of female breast cancer. Educational training on these screening techniques should be conducted to decrease breast cancer prevalence.

Male breast cancer awareness was very poor and unsatisfactory. The majority were shocked to hear about male breast cancer and unable to accept the fact that men diagnosed with breast cancer are more likely to die when compared to women. Community awareness programs should be conducted to avoid this shocking attitude towards male breast cancer and thereby reduce the prevalence of male breast cancer.

\section{REFERENCES}

1. What is Breast Cancer? CDC [Internet]. [cited 2020 Sep 17]. Available from: https:// www. cdc.gov/cancer/breast/basic_info/whatis-breast-cancer.htm 
2. Agarwal G, Ramakant P. Breast cancer care in India: The current scenario and the challenges for the future. Vol. 3, Breast Care. 2008. p. 21-7.

3. Motamedi MH, Nafissi N, Saghafinia M, Akbari M. A survey of breast cancer knowledge and attitude in Iranian women. J Cancer Res Ther [Internet]. 2012 Jan [cited 2020 Sep 17];8(1): 46. Available from: http://www.canc-erjournal .net/text.asp?2012/8/1/46/95173.

4. Sasco AJ, Lowenfels AB, Jong PP. Review article: Epidemiology of male breast cancer. A meta-analysis of published case-control studie- $\mathrm{s}$ and discussion of selected aetiological factors. Int $\mathrm{J}$ Cancer [Internet]. 1993 [cited 2020 Sep 17];53(4):538-49. Available from: https://pub med.ncbi.nlm.nih.gov/8436428/.

5. Rudlowski C. Male breast cancer [Internet net]. Vol. 3, Breast Care. 2008 [cited 2020 Sep 17]. p.183-9. Available from: https://www. karger. com/Article/FullText/136825.

6. Thomas E. Original Research: Men's Awareness and Knowledge of Male Breast Cancer. AJN, Am J Nurs [Internet]. 2010 Oct [cited 2020 Dec 18];110(10):32-7. Available from: http://journals.lww.com/ooooo446-20101000 o-00027.

7. White J, Kearins O, Dodwell D, Horgan K, Hanby AM, Speirs V. Male breast carcinoma: Increased awareness needed [Internet]. Vol. 13, Breast Cancer Research. BioMed Central; 2011 [cited 2020 Dec 18]. p. 1-7. Available from: https://link.springer.com/articles/10.11 86/bcr2930.

8. Korde LA, Zujewski JA, Kamin L, Giordano S, Domchek S, Anderson WF, et al. Multidisciplinary meeting on male breast cancer: Summary and research recommendations. J ClinOncol [Internet]. 2010 Apr 20 [cited 2020 Dec 18];28(12):2114-22. Available from:/pmc/articles/PMC2860409/?report=abstract.

9. Karayurt Ö, Özmen D, Çetinkaya AÇ. Awareness of breast cancer risk factors and practice of breast self examination among high school students in Turkey. BMC Public Health [Internet]. 2008 Oct 17 [cited 2020 Dec 18];8(1): 1-8. Available from: https://link.springer.com /articles/10.1186/14712458-8-359.
10. Ahmed BA. Awareness and practice of breast cancer and breast-self examination among university students in Yemen. Asian Pacific J Cancer Prev [Internet]. 2010 Jan 1 [cited 2020 Dec 18];11(1):101-5. Available from: https:// europepmc.org/article/med/20593937.

11. Anwar SL, Tampubolon G, Van Hemelrijck M, Hutajulu SH, Watkins J, Wulaningsih W. Determinants of cancer screening awareness and participation among Indonesian women. BMC Cancer [Internet]. 2018 Mar 6 [cited 2020 Dec 18];18(1):1-11. Available from: https ://link.springer.com/articles/10.1186/s12885018-4125-Z.

12. Elobaid YE, Aw TC, Grivna M, Nagelkerke N. Breast Cancer Screening Awareness, Knowledge, and Practice among Arab Women in the United Arab Emirates: A Cross-Sectional Survey. Al-Wadei HA, editor. PLoS One [Internet]. 2014 Sep 29 [cited 2020 Dec 18];9 (9):e105783. Available from: https://dx.plos. org/10.1371/journal.pone.0105783.

Assessment of Knowledge and Attitude Regarding Female and Male Breast Cancer among Adults of South India 